\title{
The Place and Role of Self-Evaluation Activities of Universities in the Practice of State Accreditation
}

\author{
Elena Berezhnova ${ }^{1, a^{\star}}$, Olga Mashkina ${ }^{2, b}$, Natalya Shturbina ${ }^{3, c}$
}

1 MGIMO University, Department of World Literature and Culture, 119454, 76, Vernadskogo, Prospect, Moscow, Russia

2 Moscow State University named after M. V. Lomonosov, Department of Chinese Philology, Institute of Asian and African Countries, 119991, 1 Leninskie Gory str., Moscow, Russia

3 RANEPA, Department of Project Management in the Field of Education, Center for the Development of Educational Systems, 119571, 82 Prospect Vernadskogo, Moscow, Russia

alina164@yandex.ru, boliya-m@yandex.ru, ${ }^{c}$ razvitiev@bk.ru

${ }^{*}$ Corresponding author

\begin{abstract}
Keywords: state accreditation, assessment of the quality of higher education, state-public expertise, accreditation independent centers, joint educational programs; programs of diplomas, assessment of the sustainable development management system, projects for the development of universities, project management, self-assessment of the activities of universities
\end{abstract}

\begin{abstract}
The authors' article is devoted to the problem of evaluating activities of universities. There are two approaches to its organization. The first involves the evaluation of state education authorities or public organizations funded by the government. The second is implemented through self-assessment of a university to identify shortcomings and develop measures to eliminate them and improve the quality of education.
\end{abstract}

Attention is drawn to the fact that in recent years, in the universities of many countries, including Russia and China, along with state accreditation, the practice of self-assessment activities has become widespread. The assessment is carried out by special intra-university quality assessment departments, which regularly monitor the quality of education and its management. This process has a number of advantages: maintaining a high level of teaching, updating the content of educational programs and academic disciplines, encouraging teachers to improve themselves and create. On the other hand, this process creates difficulties for the pedagogical systems of universities and those systems that manage them. The authors propose to make the project tools for managing their sustainable development an object of self-assessment of universities.

The article attempts to determine the place and role of self-assessment of universities in the functioning and development of the higher education system.

\section{Introduction}

An analysis of the reforms in Russian higher education shows that at the present time students are building various strategies for lifelong education, and an important element in them is the orientation towards acquiring foreign educational experience [20]. This trend has led to a marked increase in the number of master's programs [21] and changes in the international activities of leading universities. They began to develop joint programs and double degree programs at all levels of education (Bachelor, Master, and postgraduate) [16], [17]. In this new area of activity, universities face problems that make it difficult to assess the quality of educational programs for vocational training and promote them on the world market of educational services [6].

Among the well-known procedures for assessing the quality of higher education in different countries of the world are licensing, certification, accreditation, expert public assessment, and rating (ranking). By type of evaluation of higher education, countries of the world can be represented as two groups. (1) Countries in which the assessment is carried out by public education authorities or public organizations financed by the government (Germany, France, Russian Federation, CIS countries). (2) Countries that do not have a centralized state administration of higher education, carry out self-assessment by the universities themselves, or carry out professional expert assessment to identify shortcomings and develop measures to 
eliminate them and improve the quality of education (USA, Taiwan).

It should be noted that in recent years, conduction of self-assessment has become widespread in universities in many countries, including in Russia. Assessment is carried out, as a rule, by special internal university quality assessment departments, which regularly monitor the quality of education and its management. Increasingly, students are attracted to assess the content of an academic discipline and the degree of their participation in its formation, as well as satisfaction with the quality of teaching and the results achieved.

It is known that the development of any system depends on its management model, and on the inclusion of all its elements in the development processes. In 2016, in the Russian Federation, the start was given to the implementation of project management [10] as an effective tool for developing systems, and a recommendation was given to its application in various fields. In the past two years, the higher education system has been actively considering issues of project management, attempts are being made to reform the management model of universities using project management. All this speaks about the importance of the presented approach in the development of universities and the need to include this element in the selfassessment of their activities.

In this regard, it is necessary to determine the place and role of self-assessment of universities in the functioning and development of the higher education system.

\section{Methodology and research methods}

As part of the cultural approach, methods of describing, analyzing, comparing and summarizing the experience of universities in Russia and China were used to determine specifics of the development and application of self-assessment procedures for universities.

\section{Results of the study}

The internationalization of higher education and the expansion of international cooperation of universities contributed to increased attention to foreign students, ways to attract them, active participation in international rankings. Thus, a special structure has been established in the Ministry of Education of the People's Republic of China, which carries out a comprehensive assessment of the management quality of joint Chinese-foreign educational institutions, determines the relevance of the content and learning outcomes to both the goals and objectives stated in the training programs and to the national interests of the country [24].

Along with this, individual Chinese provinces and universities are creating their centers for assessing educational outcomes. For example, in the economically developed coastal province of Guangdong, where universities are focused on training personnel for innovative companies and enterprises located in the eastern region, a multi-level control over the quality of education has been established. The Research Center for Education Evaluation and Development (The Guangdong Center of Evaluation and Development Research for Education (GDCEDRE, htpp: //www. Gdhed.edu.cn) was created there, which functions include analyzing the development strategy of universities in the province as a whole, managing efficiency in parts of implementing the mission, goals, objectives, and using funds and resources. The Center assesses the quality of university science and educational activities, primarily, the content of programs, the organization of educational activities, and the qualifications of scientific and pedagogical staff. One of the leading universities in this province, Sun Yatsen University, also opened its own center, which organizes self-assessment of the quality of education (Center for Education Assessment of Sun Yatsen University) [19]. The assessment takes into account the views of graduates, employers, teachers, and university students.

In Russian higher education, the Federal Service for Supervision in Education and Science makes a comprehensive assessment of universities. Currently, several types of accreditation are being implemented, covering both the level of educational institutions and individual educational programs. In higher professional education, accreditation is carried out in three areas: (1) improving the system of state accreditation of educational organizations; (2) the creation of a nationwide social and professional system of independent accreditation of educational programs of universities based on a network of independent accreditation centers (IAC); (3) integration of the national system of state-public accreditation in the 
international system of accreditation of universities.

It should be noted that the first direction is developing most actively. The second direction is developing slowly, since few independent accreditation centers have been created. The results of their assessment do not exempt universities from the need for state accreditation; therefore, for a university, passing two assessment procedures is a difficult test. In the development of the third direction, only a small part of higher education institutions is interested, i.e. those universities which actively participate in international cooperation and the programs of Russian education on export.

As a rule, accreditation is preceded by an internal assessment of the university. Guided by the normative documents ([1], [2], [3], [4], [5], [7], [9], [11], [13]), special units of the university focus on the following aspects that are subject to mandatory internal self-assessment of the quality of education.

\section{The quality of educational results:}

- subject learning outcomes;

- metasubject learning outcomes;

- personal results.

2. The quality of the implementation of the educational process:

- basic educational programs;

- additional educational programs;

- implementation of academic plans and work programs;

- the quality of classroom and individual work with students;

- the quality of extracurricular activities;

- student satisfaction with learning quality.

\section{Quality conditions that ensure the educational process:}

- logistical support, campus infrastructure;

- information development environment;

- psychological climate;

- personnel;

- program-related materials, document flow, and local regulatory acts.

Activities related to the internal self-assessment process begin one year before state accreditation. This allows a university to solve many problems and prepare for the next test. Among advantages of such work are the following: maintaining a high level of teaching; updating the content of educational programs and academic disciplines; stimulating teachers to self-improvement and creativity; technical re-equipment of universities. However, there is another side to this process: the long-term psychological stress experienced by teachers because of combining practical activities with scientific and organizational ones, mainly aimed at preparing for accreditation.

Of course, the new task is to ensure the quality of international joint educational programs. Under the "joint program" is understood as an integrated curriculum, agreed and proposed by different institutions of higher education, involving the receipt of double / multiple diplomas or a joint diploma. As a rule, in joint programs where several universities participate, responsibility for internal quality assurance and control procedures remains with the university that confers a degree [18].

Summarizing the experience of leading universities ([8], [12], [14], [15], [16], [17], [18], [19], [22]), one can single out a number of conditions conducive to the successful implementation of joint programs, as well as give recommendations on their promotion to the international market. 
- Students who receive an education through a joint educational program should be guaranteed that the program meets the standards and quality criteria, regardless of location and technology implementation.

- The university where a student is studying should provide the necessary resources for its implementation, create appropriate conditions of stay and provide an academic environment for the entire period of study.

- Expand the range of educational programs to meet various educational and professional needs of students, including through additional education programs, for example, regional geographies, aimed at in-depth familiarity with the national culture, history, language; additional programs of a humanistic nature, acquainting with national and general cultural values, bringing up such socially and personally important qualities as tolerance and respect for other cultures, political and religious diversity and pluralism.

- Whenever possible, unify the design of introducing introductory information about educational programs published on websites that are popular with foreign applicants with the mandatory inclusion of the following sections in their description: program purposes, areas and types of future professional activity of graduates; a list of competences corresponding to the activities; curriculum structure; annotation of main academic disciplines and practices; feedback from graduates and employers.

- Expand the range of educational programs offered in the countries of regional unions, since they send the majority of foreign students to Russian universities.

The above conditions can become the objects of internal self-assessment and objects of external evaluation for those universities that participate in the state program that promotes the export of Russian higher education. In addition, to improve the efficiency of higher education institutions, it is necessary to include aspects of project management in the processes of self-assessment, which allow launching new innovative ideas in the development of universities in a short time. Of course, the creation of such conditions requires time and money.

\section{Conclusion}

Assuring the quality of higher education is promoted by various assessment procedures: licensing, certification, accreditation, expert public assessment, rating (ranking). The study shows that in countries where the internal comprehensive assessment of universities (Russia, China) is carried out, internal selfassessment is disseminated. It certainly has advantages as it contributes to the constant movement and change in the life of the university. Meanwhile, it is a difficult test all university structures in the last year before state accreditation. In order to reduce the pressure of the internal self-assessment of the university activities, in our opinion, it should be made part of the daily practice of all participants in the educational process. However, they must be specially prepared for this type of activity. It is necessary to begin offering students and scientific-pedagogical workers of the university to answer the following questions: what should students learn? under what conditions will they master it well? how do we know about this? how can this information affect the process of education? Further, on the basis of the obtained operational data, provide an analysis of the management model of universities, including in terms of project management demanded by modern state policy.

Thus, the results of self-assessment can serve as a basis for self-improvement of universities, preserving the quality of education and competitiveness.

\section{References}

[1] Government of Russia. (2013). Resolution of the Government of Russia of 08.05.2013 No. 662 "On implementing the education system Monitoring." Moscow, Russia.

[2] Government of Russia. (2014). Order of the Russian Ministry of 01.15.2014, No 14 "On approval of the education system of monitoring indicators." Moscow, Russia. 
[3] Ministry of Education and Science of Russia. (2014). Order of the Ministry of Education and Science of Russia No. 657 of June 11. Moscow, Russia.

[4] Ministry of Education and Science of Russia. (2014). Order of the Ministry of Education and Science of Russia dated August 27, 2014 No. 1146 "On approval of the form of the final report on the results of the analysis of the state and prospects for the development of the education system". Moscow, Russia.

[5] Rosobnadzor. (2015). Order of Rosobnadzor of 03.12.2015 No. 279. Moscow, Russia.

[6] Center for Sociological Research. (2016). Prospects and problems of training foreign citizens in Russian institutions of higher education. Moscow, Russia: CSR.

[7] Rossotrudnichestvo. (2014). The concept of promoting Russian education (on the basis of representative offices of Rossotrudnichestvo) abroad dated March 27, 2014. Retrieved from http://prev.rs.gov.ru/sites/default/files/koncepciya_prodvizheniya_rossiyskogo_obrazovaniya_v_razdel _ekport_ro.pdf.

[8] Ministry of Education and Science of Russia. (2015). Guidelines for the organization of educational activities using online forms of educational programs (letter of the Ministry of Education and Science of the Russian Federation dated August 28, 2015 No. AK-2563/05). Moscow, Russia.

[9] Government of Russia. (2013). Decree of the Government of Russia No. 662 "On Monitoring the Education System” dated August 5, 2013, No. Pr 240. Moscow, Russia.

[10] Government of Russia. (2016). Resolution of the Russian Government "On the organization of project activities in the Government of the Russian Federation” № 1050 of 10.15.2016. Moscow, Russia.

[11] Presidential Council for Strategic Development and Priority Projects. (2016). The passport of the Priority Project "Development of the Export Potential of the Russian Education System." Retrieved from http://static.government.ru/media/files/DkOXerfvAnLv0vFKJ59ZeqTC7ycla5HV.pdf.

[12] Internauka. (2018). The official website of the operator of the Olympiad "Time to study in Russia!" Retrieved from http://intnauka.ru/index.php/olimpiady.

[13] GarantBase. (2016). The Federal Law on the Independent Qualification Assessment from 07.03.2016, №238-FL. Moscow, Russia.

[14] RANX. (2018). Analysis of the best practices of Russian universities to attract foreign students. Moscow, Russia: RANX.

[15] Arefyev, A. L., \& Sheregi, F. E. (2016). Export of Russian educational services. Statistical collection. Issue 6. Moscow, Russia: Center for Sociological Research.

[16] Burkel, N., Tvorogova, S., \& Shenderova, S. (2014). Innovations and changes in transnational education: Joint programs between European and Russian universities. Moscow, Russia: Representation of the European Union in the Russian Federation.

[17] Vershinina, I. A., Kurbanov, A. R., \& Panich, N. A. (2016). Foreign students in Russia: features of motivation and adaptation. University management: practice and analysis, 106(6), pp. 122-147.

[18] Zabotkina, V. I., \& Makolov, V. I. (2016). Implementation of the provisions of European standards and recommendations for quality assurance in the framework of international joint educational programs. Integration of Education, 20(4), pp. 446-455.

[19] Zapryagaev, S. A., Karavaeva, E. V., Karelina, I. G., \& Saletsky, A. M. (2007). Globalization and quality assurance systems of higher education. Moscow: Publishing House of Moscow State University.

[20] Kurdenkova, O. P. (2015). Strategies for continuing education of Russian students: options for building. Domestic and Foreign Pedagogy, 5(26), pp. 156-164. 
[21] No author. (2016) Master's degree in Russia: demand and supply growth, differentiation by region and university. Education Facts, 9.

[22] Mashkina, O. A, (2018). Cooperation in the educational sphere in the Eurasian space: state and prospects (on the example of China, Russia, and Kazakhstan). In The Eurasian civilization: History and the present: Collection of materials of the international scientific-practical conference (pp. 117128). Ulaanbaatar, Mongolia.

[23] WinBD. (2018). Project management in higher education and science. Retrieved from http://winbd.ru/news/2019.

[24] CRS. (2018). Regulations of the People's Republic of China on Chinese-Foreign Cooperation in Running Schools (中华人民共和国教育部 中外合作办学监管工作信息平台). Retrieved from htpp://www.crs.jsj.edu.cn/news/index/24.

[25] QS Digital Solutions. (2016). What matters to international students? Global overview. Retrieved from http://www.iu.qs.com/product/global-overview. 